\title{
EFFECT OF TRIDAX PROCUMBENS HYDROETHANOLIC EXTRACT ON WISTAR RATS BLOOD GLUCOSE, TOTAL CHOLESTEROL, AND TRIGLYCERIDES
}

\author{
${ }^{*}$ Koukoui $\mathrm{O}^{1,2}$, Medegan $\mathrm{S}^{3}$, Senou $\mathrm{M}^{4}$, Guinra $A^{1,2}$, Koumayo $\mathrm{F}^{1,2}$, Adjagba $M^{5}$, Agbagnan $\mathrm{P}^{6}$, Laleye $A^{5}$ \& Sezan $A^{2}$ \\ ${ }^{1}$ Laboratory of Animal Physiology, Cellular Signalisation and Pharmacology, University of Sciences Technologies, engineering \\ and Mathematics, BP 34 Dassa Zoume, Benin \\ 2Laboratory of Biomembranes and Cellular Signalisation, University of Abomey-Calavi Cotonou Benin 01 BP 188 Cotonou Benin \\ ${ }^{3}$ Medicinal and organic chemistry Laboratory, Faculty of health Sciences, 01BP 188 Cotonou Benin \\ ${ }^{4}$ Research Laboratory in Applied Biology, Polytechnic School of Abomey Calavi, University of Abomey Calavi 01 BP 2009 \\ Cotonou Benin \\ ${ }^{5}$ Human Biology Unit, Faculty of Health Sciences, 01BP 188 Cotonou Benin \\ ${ }^{6}$ Laboratory of Studies and research in Applied Chemistry University of Abomey-Calavi (LERCA/UAC), Cotonou, Benin
}

\begin{abstract}
The hypoglycemic, hypotensive and antioxidant effects of Tridax procumbens have been fundamentally studied in India where the plant is widely used for its medicinal properties. In this work, we treated Wistar rats with two doses of leaves and stems hydroethanolic extract of Benin species of Tridax procumbens every day for 15 days. Three groups of 5 rats were formed, the first control group was treated with $1 \mathrm{ml}$ of water every day, the second group was treated with $1 \mathrm{ml}$ of $300 \mathrm{mg} / \mathrm{kg}$ body weight of extract and the third group was treated with a dose of 500mg / $\mathrm{kg}$ body weight every day. Histological studies of the liver and kidney of untreated and treated animals was made to check the toxicity of the extract. Our results demonstrated after 15 days of treatment that none of the doses used has a significant effect on rat blood sugar however we observed a dose dependent effect on lowering blood cholesterol levels compared to controls and a decrease of blood triglycerides levels by the dose of $300 \mathrm{mg} / \mathrm{kg}$ body weight compared to controls. The two doses used were not toxic to the liver or the kidneys. Tridax procumbens hydroethanolic extract through its regulation of lipid levels in the blood of Wistar rats could fight against dyslipidemia in obese, added to its antioxidant activity the extract could prevent type II diabetes and cardiovascular diseases.
\end{abstract}

\section{KEY WORDS}

Tridax procumbens-Wistar rats-cholesterol-triglycerides

\section{INTRODUCTION}

Obesity is defined as excess body fat causing inconvenience to the somatic, psychological and social health [1]. When it is intra-abdominal, it represents a major risk factor for the onset of noncommunicable diseases such as cardiovascular diseases, diabetes, and cancer [2-3], which are the leading cause of death in both developed and developing countries. In obese women, the high ratio (visceral adipose tissue/subcutaneous adipose tissue) is associated with high blood pressure regardless of age and body mass index [4-6]. The chronic nature of these diseases and the high costs of treatment bring the patients in poor countries to turn to traditional medicine that offers leaves, stems and roots, infusions with obvious therapeutic values.

Tridax procumbens (Tridax $p$ ) is plant species of the Asteraceae family, native to Central America and South 
America but was introduced in tropical, subtropical, and temperate regions of the world [7]. The plant is known as "azuiman" in "Fon" a language of Benin. It was subject to several studies for its medicinal properties. The phytochemical screening of the plant revealed the presence of flavonoids, tannins, reducing sugars and phenolic acids [8], previous works put in evidence alkaloids, terpenoids, saponins in the plant [9-10]. Aqueous and alcoholic extracts of Tridax $p$ leaves showed significant hypoglicemic and anti-diabetic activities in rats intoxicated with alloxan at $200 \mathrm{mg} / \mathrm{kg}$ body weight after 7 days of oral administration [11]. The administration of aqueous extract of Tridax. $p$ at $20 \mathrm{mg}$ / $100 \mathrm{~g}$ to Wistar rats contributed to the significant reduction of triglyceride concentration, LDL, VLDL and total cholesterol while the HDL levels were significantly higher in treated rats [12]. Triglyceride mainly derived from diet and sugar metabolism [13]. They are carried by VLDL and stored in adipose tissue as reserve [14]. High sugar diet and sedentary lifestyle result in non-use of triglyceride reserves and the onset of obesity. Many studies had also established the link between high triglyceride and coronary diseases [15-16]. Hypercholesterolemia is characterized by the presence in the blood of a higher number of small dense LDL particles [17], these LDL particles are associated with the development of atherosclerotic plaque leading directly to cardiovascular complications [18-19]. In this work, we tried to study in vivo in Wistar rats the hypolipidemic activity of hydroethanolic extract of Tridax $p$ observed in vitro with HepG2 cells and a possible in vivo hypoglycemic effect.

\section{MATERIALS AND METHODS}

\section{A Materials \\ 1 Collection of Tridax $p$ plants}

Tridax $p$ plants were collected in the month of May, 2015 from Abomey Calavi a small city of Benin. A specimen was deposited in the National Herbarium of the Department of Botany, Abomey-Calavi University. Samples were dried in shade at room temperature $\left(25^{\circ} \mathrm{C}\right)$ until stabilization of their mass and then pulverized into coarse powder.

\section{Animal Material}

The experimental animals are male and female Wistar rats weighing between 150 and $250 \mathrm{~g}$. All animals have health status of SPF (specific pathogen Exempt). Work on wistar rats were authorized by the national committee of ethics of Benin science academy. Upon receipt, the rats were randomly placed in groups of five (5) in standard cages for a period of acclimatization (2 weeks) before being used in various experiments. During this period the animals had free access to food and water and remained kept at constant temperature $(22 \pm 2)^{\circ} \mathrm{C}$. They were exposed to a light / dark cycle
$12 \mathrm{~h} / 12 \mathrm{~h}$. The dark phase of the cycle begins at $12 \mathrm{~h}$ and different experiences have always been held from $11 \mathrm{AM}$ to $6 \mathrm{PM}$ due to the nocturnal activity (active phase) of rats.

\section{Other equipment and Reagents}

Pasteur pipettes, syringes; filter papers, cotton, gloves, hematocrits tubes probe are provided by "Comptoir Scientifique" (Cotonou Benin); assay kits supplied by Sigma (France).

\section{B Methods}

\section{Tridax $p$ leaves and stems extraction}

All samples were ground in a commercial coffee grinder for extraction. The mixture ethanol-water $50 \%(\mathrm{v} / \mathrm{v})$ was used as extraction solvent. The extract was concentrated in vacuo using a rota vapor and the yield (Y) was calculated by the formula below:

$Y(\%)=$ (Mass of extract) / (Mass of plant material used) $\mathrm{X} 100$

\section{Blood sampling and rats weighing}

Blood sampling and rats weighing took place on day $=0$ and day $=15$ before and after fifteen days treatment with hydroethanolic extract of Tridax $p$. Regarding sampling, $2 \mathrm{ml}$ of blood were taken with hematocrit tube through the retro-orbital sinus of rat eyes. Blood were collected in dry tubes and were immediately centrifuged at $4000 \mathrm{rpm}$ for 10 minutes at $10^{\circ} \mathrm{C}$ for the analysis of biochemical parameters.

\section{Rat feeding}

After a blood sampling for the determination of parameters to be studied before and after treatment, the rats are force-fed daily at 11 am for 15 days with either water or extract solutions. The administration of extracts is made orally as follows: we have fifteen (15) rats divided into three (3) groups. Each group has five (5) rats. The control rats group fed with $1 \mathrm{ml}$ of water each day. A second group of five (5) rats received $1 \mathrm{ml}$ of $100 \mathrm{mg} / \mathrm{ml}$ of extract equivalent to $300 \mathrm{mg} / \mathrm{kg}$ of body weight each day. The last group of five (5) rats received $1 \mathrm{ml}$ of $150 \mathrm{mg} / \mathrm{ml}$ of extract corresponding to $500 \mathrm{mg} /$ $\mathrm{kg}$ of body weight each day.

4 Determination of glucose concentration in the blood It is a colorimetric assay following two coupled enzymatic reactions. A closely specific enzymatic reaction (glucose oxidase) oxidizes glucose present in the sample to gluconic acid and hydrogen peroxide. It serves as the substrate for the peroxidase in a coupled reaction resulting in the oxidation of o-dianisidine to a colored product. The intensity of the color is proportional to the glucose concentration. A capsule of enzymes (glucose oxidase-peroxidase) is dissolved in $100 \mathrm{ml}$ of water followed by $1.6 \mathrm{ml}$ of solution of odianisidine. The reagent is ready to use and can be kept several days in the refrigerator. We conducted a blank tube containing only distilled water $(20 \mu \mathrm{l})$, two standard tubes containing $20 \mu \mathrm{l}$ of glucose $(1 \mathrm{~g} / \mathrm{l})$. And then we 
have prepared two tubes each containing $20 \mu \mathrm{l}$ of supernatant (blood plasma) for each sample. $2 \mathrm{ml}$ of reagent was then added into each tube and all placed in an oven at $37^{\circ}$ for 10 minutes. After steaming completed, the absorbance was measured by spectrophotometry at $470 \mathrm{~nm}$, taking as zero the white tube. We kept the average of the two values for duplicate tubes when they are compatible. The glucose concentration is found with the following calculation: $[\mathrm{G}]=$ Do $/$ Dsg $\times$ Csg

With: Do = absorbance, Dsg = Do standard glucose, Csg = concentration standard glucose

5 Determination of triglycerides concentration in the blood [20]

The triglyceride samples were incubated with the lipoprotein lipase (LPL) and glycerol and fatty acids were released. Glycerol was converted to glycerol 3phosphate (G3P) and adenosine-5-diphosphate (ADP) by glycerol kinase and ATP. Glycerol 3-phosphate (G3P) was then transformed with glycerol phosphate dehydrogenase (GPO) to dihydroxyacetone phosphate (DAP) and hydrogen peroxide ( $\mathrm{H} 2 \mathrm{O} 2)$. Hydrogen peroxide ( $\mathrm{H} 2 \mathrm{O} 2)$ reacted with 4- amino-antipyrine (4AP) and p-chlorophenol in the presence of peroxidase (POD) to give a red color. The intensity of the color formed is proportional to the amount of triglycerides contained in the serum sample. The absorbance was measured by spectrophotometry at $505 \mathrm{~nm}$, triglycerides concentration is given by the formula : Tryglycerides rate $(\mathrm{g} / \mathrm{I})=(\mathrm{DOD} / \mathrm{DOE}) \times 2 ; \mathrm{DOD}=$ absorbance of samples, $\mathrm{DOE}=$ absorbance of standard

6 Determination of total cholesterol concentration in the blood [21]

Cholesterol and its esters were released from the lipoproteins with detergents. Cholesterol esterase hydrolyzed esters. Peroxide was formed in the subsequent enzymatic oxidation of cholesterol by cholesterol oxidase. Peroxide with phenol and 4aminoantipyrine produced quinonneimine in the presence of peroxidase. The absorbance of quinonneimine was measured at $505 \mathrm{~nm}$ and is proportional to the concentration of total cholesterol Total cholesterol concentration is given by the formula: cholesterol concentration $(\mathrm{g} / \mathrm{l})=(\mathrm{DOD} / \mathrm{DOE}) \times 2$; DOD $=$ absorbance of samples, DOE $=$ absorbance of standard

\section{Rats liver and kidney histology}

After the dissection, liver and kidney were removed, fixed in buffered formalin, and embedded in paraffin. The specimen's sections $(5 \mu \mathrm{m})$ were mounted on glass slides, deparaffinated, and hydrated. For histological analysis, sections were stained with hematoxylin and eosin (H\&E), following a standard protocol [22]. The pictures were taken at 40X magnification.

8 Statistical testing
We used the standard deviation ant the Student test to check whether the effects obtained were significant.

\section{Results and Discussion}

1 Effect of the treatment with hydroethanolic extract of Tridax $\boldsymbol{P}$ leaves and stems on rat weight (figure 1)

Control and treated rats were weighed before and after treatment. Comparing the evolution of the weight of control and treated rats we noticed that the weight of control rats increased by $7,5 \%$ while the weight of treated rats decreased by $6 \%$ with extract at $300 \mathrm{mg} / \mathrm{kg}$ of body weight and by $7,4 \%$ with extract at $500 \mathrm{mg} / \mathrm{kg}$ of body weight. Tridax $p$ hydroethanolic extract could slightly reduce weight gain in treated rats. This decrease in body weight could be linked to the lipid-lowering effect of Tridax $p$ extract reported by some authors [8, 12 ]. By reducing the fat levels in the blood the extracts could decrease the accumulation of fat in adipose tissue and then prevent obesity [23].

2 Effect of Tridax $p$ leaves and stems hydroethanolic extract on wistar rats blood glucose concentration (Figure2)

Blood glucose concentration was measured in control and treated rats before and after treatment. It appears from the analysis of this graph that the blood sugar of all rats decreased. This decrease was more pronounced in rats treated with $1 \mathrm{ml}$ of $300 \mathrm{mg} / \mathrm{kg}$ of body weight for 15 days (36,17\%). Tridax $p$ hydroethanolic extract could have slight hypoglycemic effect at this concentration. These results are consistent with those of numerous authors who showed the inhibitory effect of Tridax $p$ extract on alpha amylase an enzyme which promotes the increase of blood glucose levels [24]. However the question is : can we consider this effect since it was reported that the hypoglycemic effect of Tridax $p$ extracts are only observed in diabetic rats $[11,25]$.

3 Effect of Tridax $p$ leaves and stems hydroethanolic extract on wistar rats blood total cholesterol (Figure3) Total Cholesterol concentration of control and treated rats was measured before and after treatment. Blood cholesterol levels increased in all rats probably because of the diet. However, treated rats cholesterol increase was lower than control rats cholesterol increase. Cholesterol level in control rats increased significantly $(76,50 \%, \quad p<0,01)$. This increase was reduced significantly in rats treated with dose of $300 \mathrm{mg} / \mathrm{kg}$ $(16 \%, p<0,05)$ body weight and was completely canceled in rats treated with $500 \mathrm{mg} / \mathrm{kg}$ of body weight $(1,58 \%, p<0,05)$. These results are consistent with previous works which reported a beneficial effect of Tridax $p$ extract on rats cholesterol level $[12,26]$. This lowering effect of Tridax $p$ extract is very important because the role of high level of cholesterol in the occurrence of cardiovascular diseases was demonstrated, high levels of LDL lipoproteins that carry 
a high percentage of cholesterol in the blood weakens the blood vessels via oxidative stress and is responsible for heart attacks and cardiovascular events [27-29]. Tridax $p$ aerial parts extracts contain plant sterols and flavonoids [8-9], Sterols could be responsible for the lowering effect of the plant on cholesterol level [30] and flavonoids with their high antioxidant activity could reduce $L D L$ particles oxidation and then inhibit the formation of atherosclerotic plaques in blood vessels and then reduce the risk of myocardial infarction and cerebral vascular accidents [31-32].

4 Effect of Tridax $p$ leaves and stems hydroethanolic extract on wistar rats blood triglycerides (Figure 4)

The blood triglycerides concentrations were measured in control and treated rats before and after treatment. Triglyceride levels decreased in all rats after the treatment, a decrease of $36 \%$ in controls rats, $55 \%$ in rats treated with a dose of $300 \mathrm{mg} / \mathrm{kg}$ of body weight and $17 \%$ in rats treated with a dose of $500 \mathrm{mg} / \mathrm{kg}$ of body weight. From these results we could deduce that the dose of $300 \mathrm{mg} / \mathrm{kg}$ of body weight of Tridax $p$ leaves and stems hydroethanolic extract decreased significantly triglyceride levels in rats blood. Our results are consistent with previous works which reported that Tridax $p$ extract could reduce fat in vivo and in vitro [8, $12,24]$. Triglycerides have a role of storage and provide an important pool of energy, this reserve is stored in the cells of adipose tissue that contain about $75 \%$ of triglycerides [14]. High levels of triglycerides represent an independent risk factor for cardiovascular disease [15-16]. The presence of plant sterols in Tridax $p$ leaves extracts could also explain the decrease of triglycerides in treated rats. Reducing triglycerides levels, Tridax $p$ extract could induce the stabilization or loss of weight and participate in preventing dyslipidemia observed in obese people.

5 Toxicologic activity of Tridax $p$ leaves and stems hydroethanolic extract on rats liver and kidney-Liver Histology (Figure 5)

The treatment with $1 \mathrm{ml}$ of Tridax $p$ extract at 300 $\mathrm{mg} / \mathrm{Kg}$ (Figure $5 \mathrm{~B}$ ) or $1 \mathrm{ml}$ of Tridax $p$ extract at $500 \mathrm{mg}$ / Kg (Figure 5C) did not alter the liver parenchyma. Hepatocytes as in the control rats (Figure 5A) are arranged in radial blades around the central vein Sinusoids with typical appearance between the hepatocyte bays were visible. Cellular atypia were not observed. Kidney Histology (Figure 6)

The treatment with Tridax $p$ leaves and stems hydroethanolic extract at $300 \mathrm{mg} / \mathrm{Kg}$ (Figure $6 \mathrm{~B}$ ) or 500 $\mathrm{mg} \mathrm{/} \mathrm{Kg}$ (Figure 6C) did not alter the cortical parenchyma. Just as in the control rats (Figure 6A), the cortex has typical glomeruli, proximal and distal tubules. The parenchyma did not present visible cellular atypia. The renal medulla presented the same appearance for controls (Figure 6D) and treated with low (Figure 6E) or high dose (Figure 6E). Collecting ducts are clearly identifiable. These results are similar to that obtained with Solanum macrocarpon Linn, a medicinal plant used in Benin to lower cholesterol [33] and is consistent with our previous results that has demonstrated that only a very high dose of Tridax $p$ extract could be toxic in vitro [8].

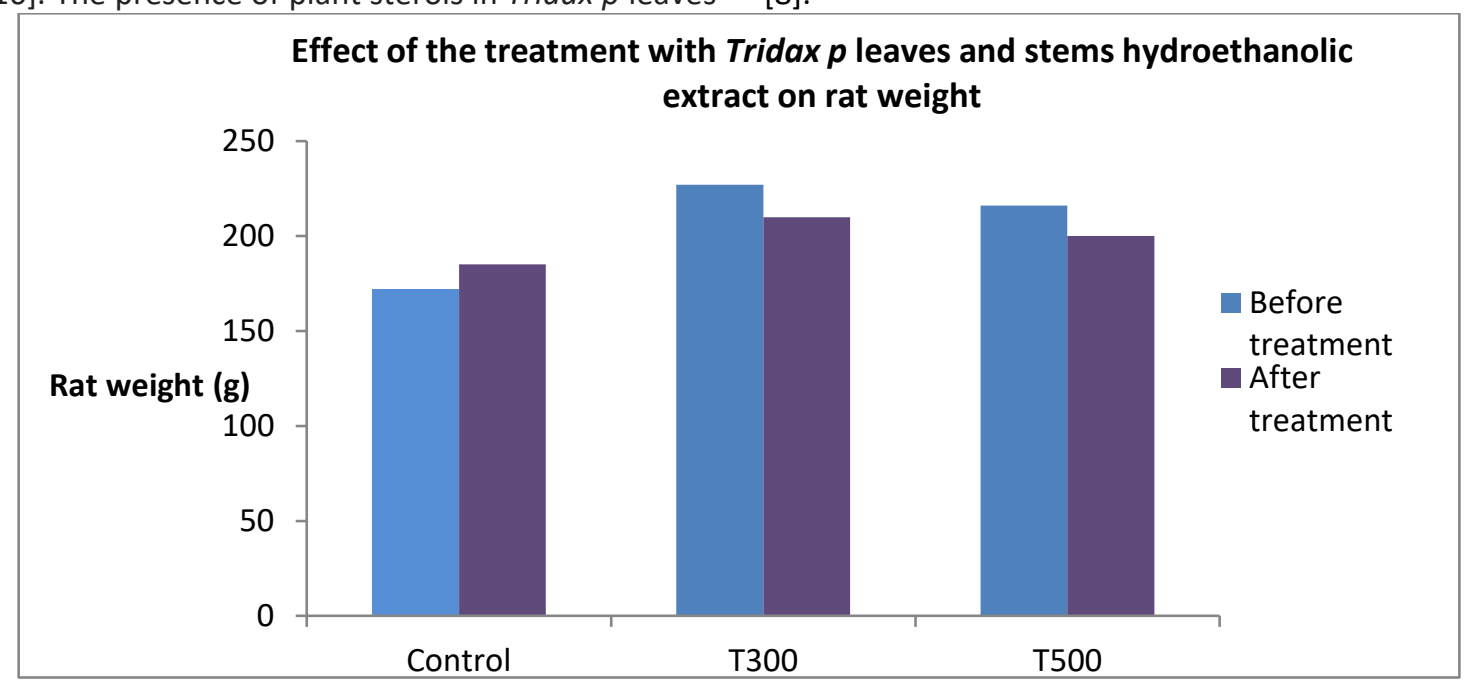

Figure1: Average of rats weight before and after treatment with hydroethanolic extract of Tridax $p$ leaves and stems

The weight of control rats that received only $1 \mathrm{ml}$ of water for 15 days increased by $7,5 \%$ after treatment while the weight of the rats that received $1 \mathrm{ml}$ of $300 \mathrm{mg} / \mathrm{kg}$ body weight of extract for 15 days decreased by $6 \%$ and the weight of the rats that received $1 \mathrm{ml}$ of 500 $\mathrm{mg} / \mathrm{kg}$ body weight of extract for 15 days decreased to 7,4\%. 


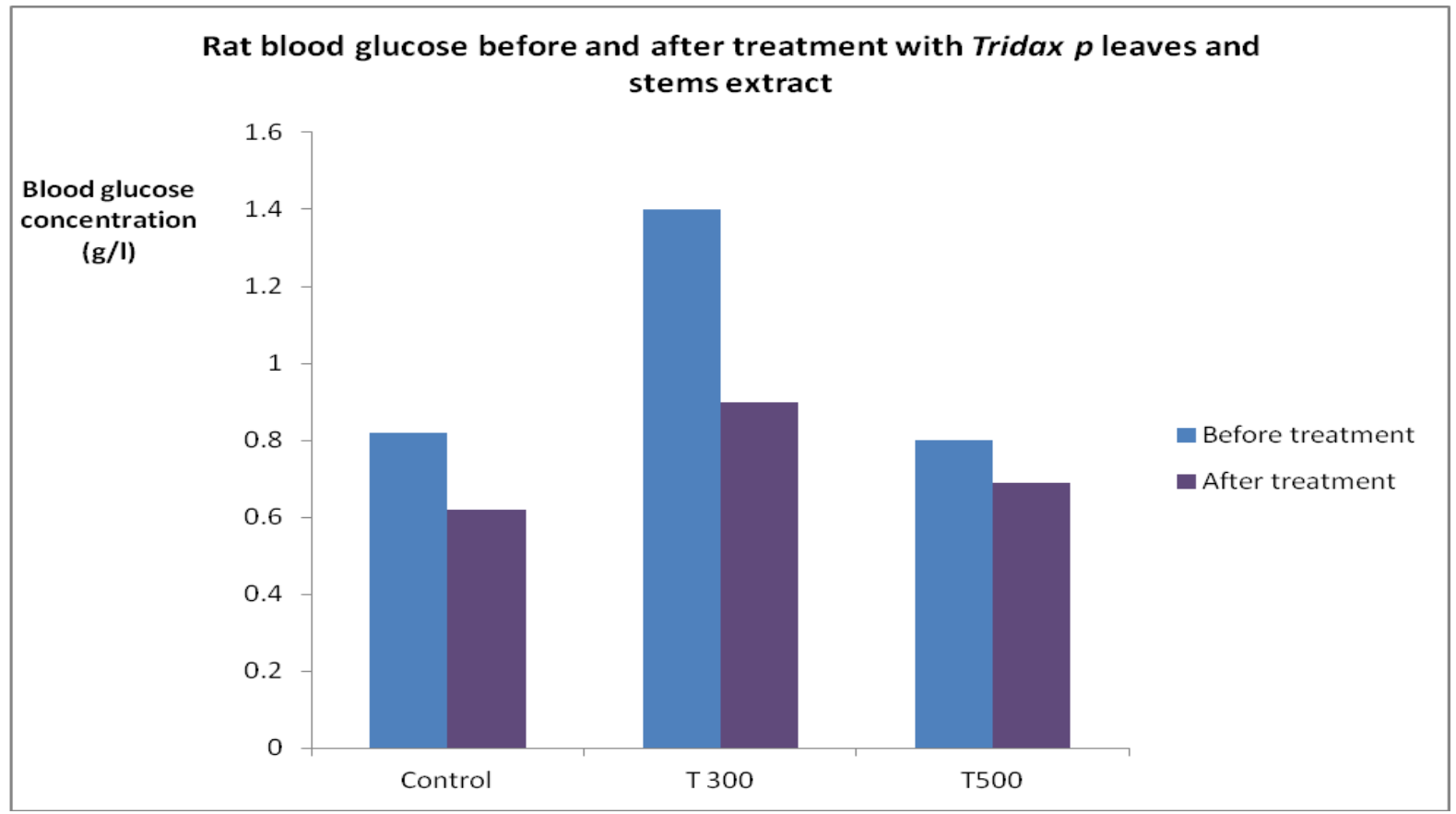

Figure 2: Wistar rats blood Glucose concentration before and after treatment

Blood glucose concentration of control and treated rats decreased: by $25 \%$ in control rats, by $36,17 \%$ in rats treated with $1 \mathrm{ml}$ of Tridax p extracts at $300 \mathrm{mg} / \mathrm{kg}$ of body weight ( $\mathrm{L} 300)$ and by $14 \%$ in rat treated with $1 \mathrm{ml}$ of Tridax $\mathrm{p}$ extracts at $500 \mathrm{mg} / \mathrm{kg}$ of body weight.

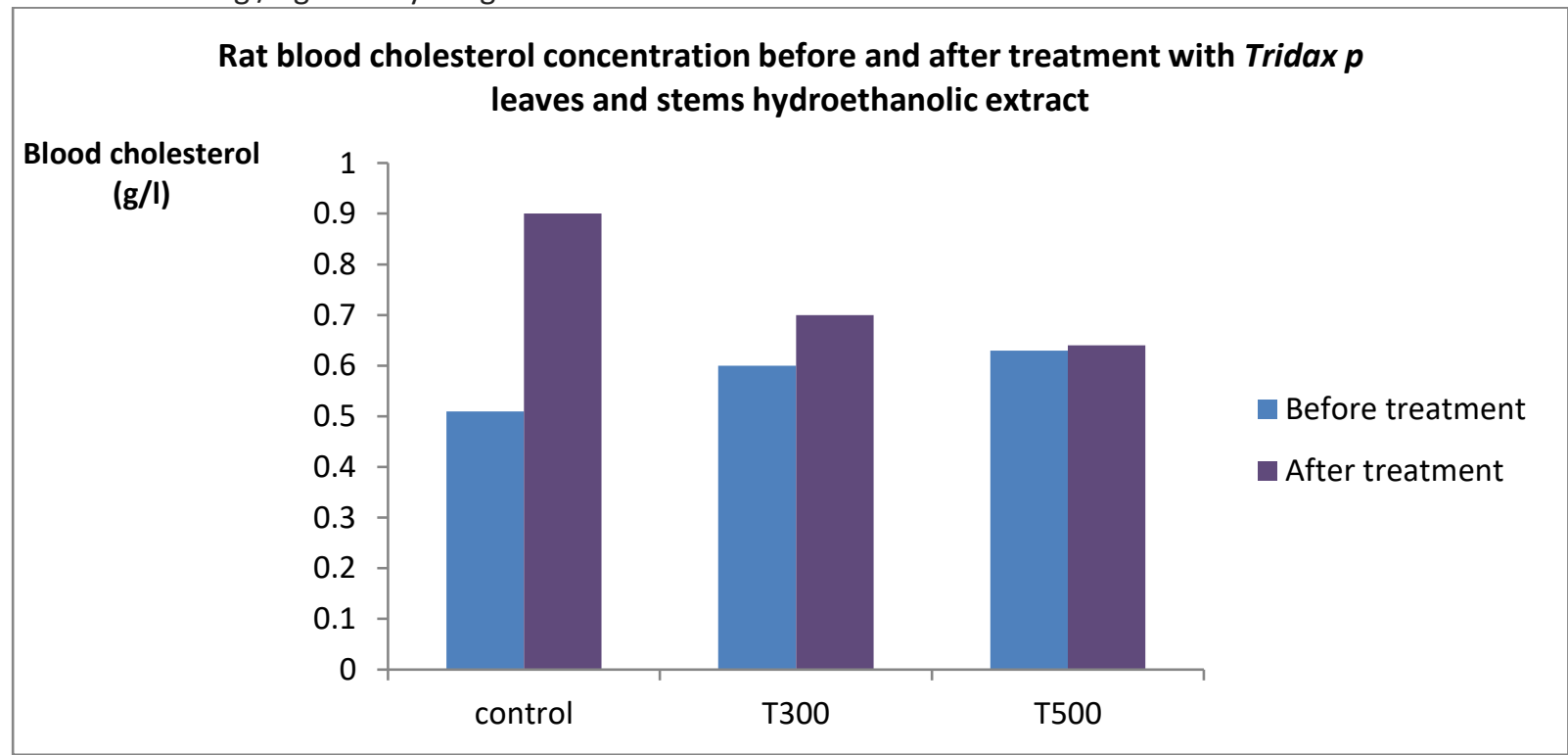

Figure 3: Wistar rats blood cholesterol concentration before and after treatment with Tridax $p$ leaves and stems hydroethanolic extract

The control rats cholesterol levels rose sharply after two weeks from $0.51 \pm 0.03 \mathrm{~g} / \mathrm{I}$ to $0.9 \pm 0.06 \mathrm{~g} / \mathrm{I}$ an increase of 76.5\%. Treated rats cholesterol also increased slightly from $0.60 \pm 0.06 \mathrm{~g} / \mathrm{I}$ to $0.71 \pm 0.05 \mathrm{~g} / \mathrm{I}$ for rats treated with $1 \mathrm{ml}$ of extract at $300 \mathrm{mg} / \mathrm{kg}$ of body weight an increase of $16 \%$ and from $0.63 \pm 0.08 \mathrm{~g} / \mathrm{I}$ to $0.641 \pm 0.06 \mathrm{~g} / \mathrm{I}$ for rats treated with $1 \mathrm{ml}$ of extract at $500 \mathrm{mg} / \mathrm{kg}$ of body weight an increase of 1,58 \% 


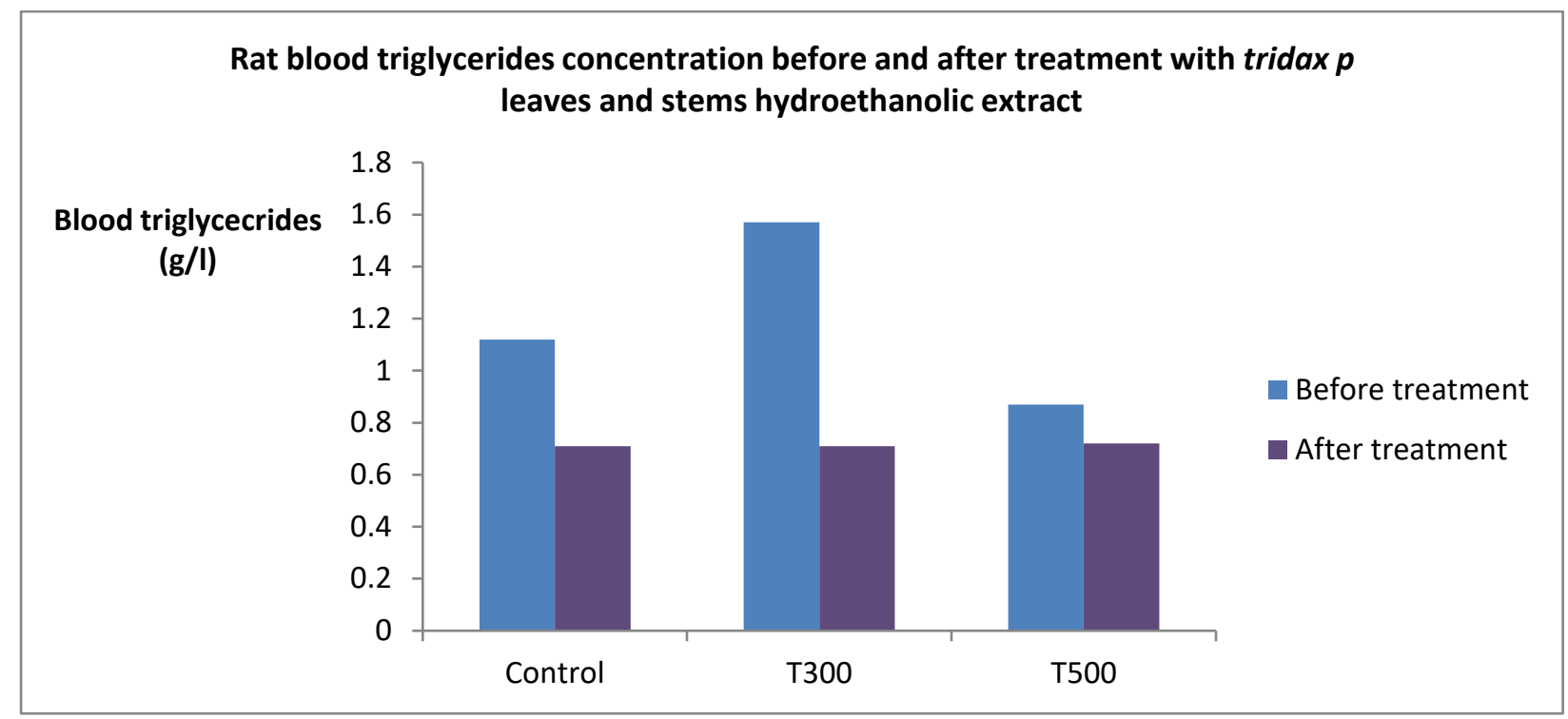

Figure4: Triglycerides concentrations in rats blood before and after treatment. Triglycerides concentration in control rat blood decreased from $1.12 \pm 0.41$ to $0.71 \pm 0.41$. Blood triglycerides concentration of rats treated with $1 \mathrm{ml}$ of $300 \mathrm{mg} / \mathrm{kg}$ of body weight decreased from $1.57 \pm 0.1$ to $0.71 \pm 0.09$ and that of the rats treated with $1 \mathrm{ml}$ of $500 \mathrm{mg} / \mathrm{kg}$ of body weight decreased from $0.87 \pm 0.06$ to $0.72 \pm 0.08$.

A

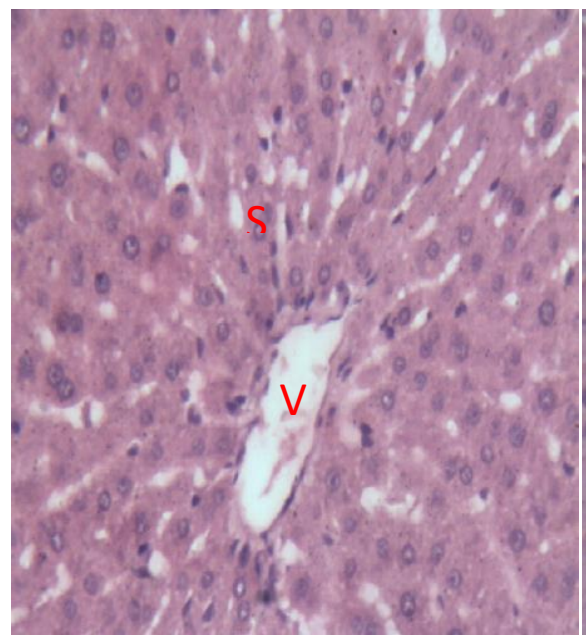

B

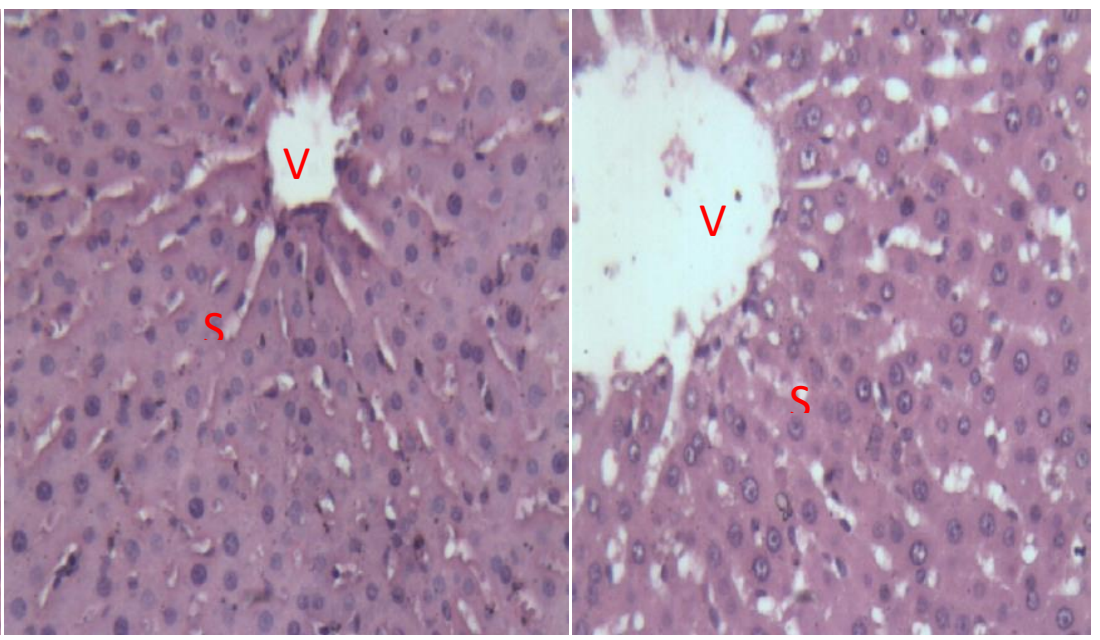

Figure 5: Liver of control and treated rats

In controls rats (figure 5A), hepatocytes were arranged in radial blades around the central vein (V). The sinusoids (S) have typical appearance. The parenchyma did not significantly change in rats treated with Tridax $p$ extract at $300 \mathrm{mg} / \mathrm{Kg}$ (figure $5 \mathrm{~B}$ ) or $500 \mathrm{mg} / \mathrm{Kg}$ (figure $5 \mathrm{C}$ ). 
A

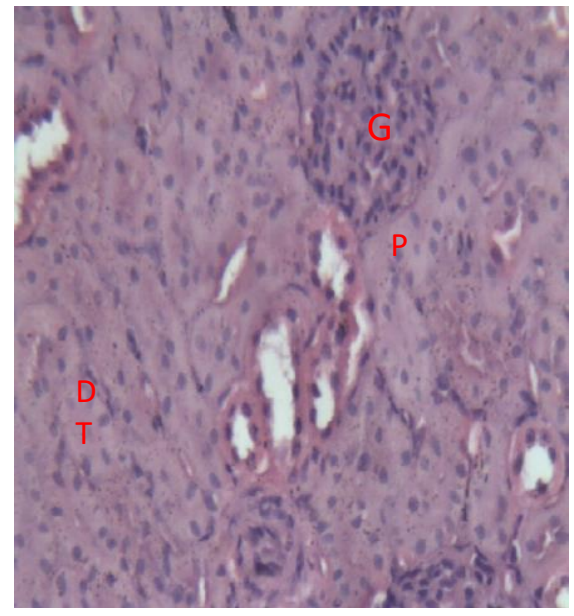

D

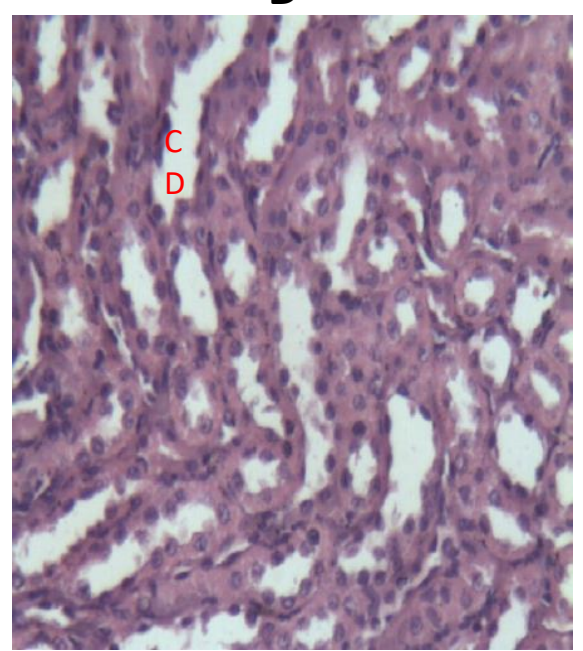

B

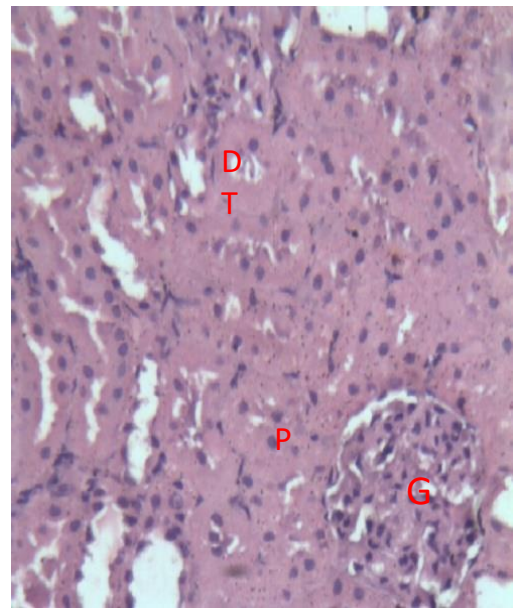

$\mathbf{E}$

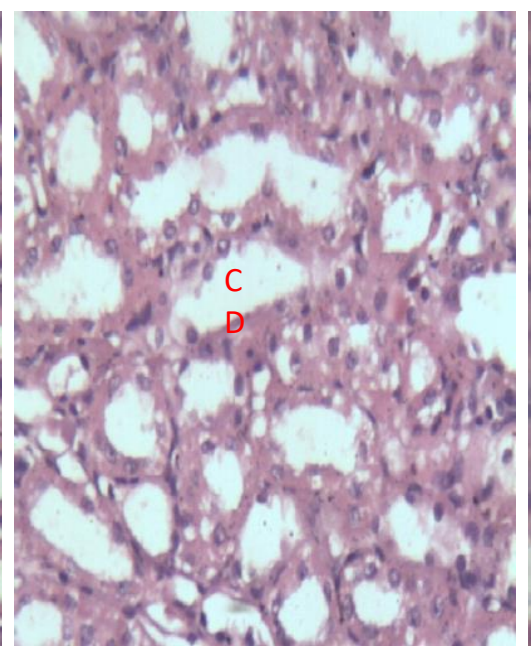

C

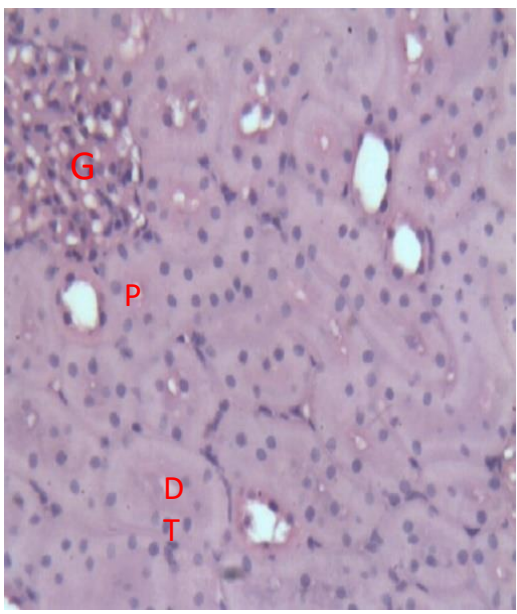

$\mathbf{F}$

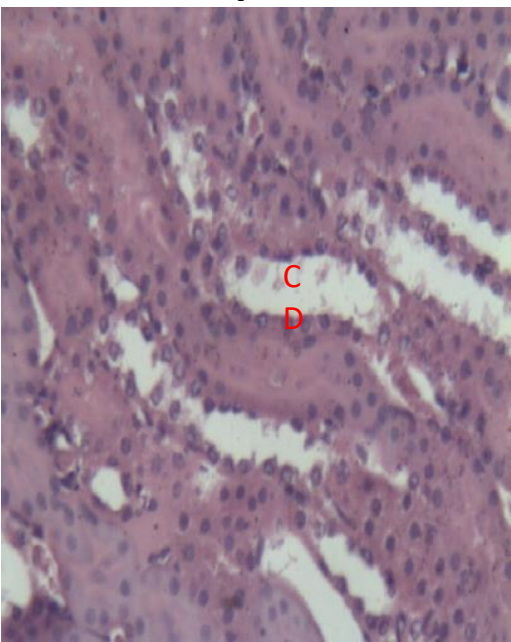

Figures 6 A, B and C: Kidney Cortex of control and treated rats Figure $6 D, E$, and F: Kidney Medulla of control and treated rats

The renal cortex of control rats (Figure 6A), rats treated with $1 \mathrm{ml}$ of $300 \mathrm{mg} / \mathrm{Kg}$ of Tridax p extract (Figure 6B) or with $1 \mathrm{ml}$ of $500 \mathrm{mg} / \mathrm{kg}$ (Figure $6 \mathrm{C}$ ) have the same characteristic architecture with glomeruli (G), proximal tubules (PT) and distal tubules (DT).

The renal medullar of control rats (Figure 6D), rats treated with Tridax p extract $300 \mathrm{mg} / \mathrm{Kg}$ (Figure 6E) or $500 \mathrm{mg}$ / Kg (Figure 6E), have the same characteristics with clearly identifiable collecting ducts (CD).

\section{CONCLUSION}

The hydroethanolic extract of Tridax $p$ leaves and stems has the property to reduce cholesterol and triglyceride levels in wistar rats. These results confirm the observations already made in vitro in HepG2 cells. By reducing the rate of circulating lipid, Tridax $p$ extract inhibit fat accumulation and dyslipidemia. Considering the important link between obesity, dyslipidemia, diabetes type II and cardiovascular diseases, Tridax $p$ hydroethanolic extract could also prevent diabetes type II and cardiovascular diseases.

\section{REFERENCES}

[1] ANAES, Agence Nationale d'Accréditation et d'Evaluation en Santé. Prise en charge de l'obésité de l'enfant et de l'adolescent, Service des recommandations professionnelles (2003).

[2] Alberti K.G.M.M., Zimmet, P \& Shaw J The metabolic syndrome--a new worldwide definition. Lancet 366 : 1059-1062 (2005). 
[3] Aldhahi W \& Hamdy O, Adipokines, inflammation, and the endothelium in diabetes. Curr. Diab Rep, 3: 293-298 (2003).

[4] Dobrian A D, Davies M J, Schriver SD, Lauterio T J, Prewitt $R L$, Oxidative stress in a rat model of obesity-induced hypertension. Hypertension 37: 554-560 (2001)

[5] Hayashi T, Boyko EJ, Leonetti DL, McNelly MJ, NewellMorris L, Khan SE, Fujimoto WY, Visceral adiposity, and the prevalence of hypertension in Japanese Americans. Circulation 108: 1718-1723 (2003).

[6] Kannel WB, Metabolic risk factors for coronary heart disease in women: perspective from the Framingham study, Am Heart J, 114: 413-9 (1987).

[7] Jahangir M, Chemical and Biological Studies on Some Members of Asteraceae Family and Pseudocalymma elegans, a Native of Brazil. PhD thesis submitted to the International Center for Chemical Sciences H.E.J, Research Institute of Chemistry (2001).

[8] Koukoui $O$, Agbangnan $C P$, Medoatinsa DE, Prigent $S$, Nusse $O$, Combettes L, Sohounhloue D, Chemical Profile, Cytotoxicity Anti-Radical and Hypolipidemic Activities of Tridax Procumbens of Benin, RJPBCS, 6(4): 1441-1449 (2015)

[9] Edeoga HO, Okwu DE, Mbaebie BO, Phytochemical constituents of some Nigerian medicinal plants. Afr. J. Biotechnol, 4(7): 685-688 (2005).

[10] Reddy STVV, Prasanthi S, Naidu Ramarao BVA, Traditional phytotherapy for jaundice. In Herbal Medicine: Traditional Practices, Trivedi PC (ed). Aavishkar Publishers: Jaipur, 30-68. 2006

[11] Bhagwat DA, Killedar SG, Adnaik RS, Anti-diabetic activity of leaf extract of Tridax procumbens, Int. J. Green. Pharm., 2: 126-128 (2008).

[12] Ikewuchi Chigozie and Ikewuchi Chidinma Catherine, Alteration of plasmalipid profil and atherogenic indices of cholesterol loadedrats by Tridax procumbens Linn : Implications for the management of obesity and cardiovascular diseases.Biokemistry, 21(2): 95-99 (2009).

[13] Raisonnier A, Lipides et lipoprotéines. CHU-PS. Université PARIS-VI Pierre et Marie Curie. Faculté de Médecine Pitié-Salpêtrière, (2003).

[14] Garaulet M, Hernandez-MoranteJJ, Tebar FJ, Zamora S, Relation between degree of obesity and site specific adipose tissue fatty acid compositionin a mediterranean population, Nutrition, 27: 170-176, (2011).

[15] Hokanson JE, Austin MA, Plasma triglyceride level is a risk factor for cardiovascular disease independent of highdensity lipoprotein cholesterol level: a meta-analysis of population-based prospective studies. J Cardiovascular Risk, 3: 213-9 (1996).

[16] Sarwar N, Danesh J, Eiriksdottir G, Triglycérides and the risk of coronary heart disease: 10158 incident cases among 262525 participants in 29 Western prospective studies, Circulation, 115: 450-8, (2007).

[17] Stapleton PA, Goodwill GA, James ME, Brock WR, Frisbee JC, Hypercholesterolemia, and microvascular dysfunction: interventional strategies, Journal of Inflammation, 7:54, (2010)

[18] Heistad D.D, Oxidative stress and vascular disease. Arterioscler Thromb Vasc Biol., 26 (4), 689-695, (2006).
[19] Zambon, A, Hokanson, JE, Brown BG, Brunzell JD, Evidence for a new pathophysiological mechanism for coronary artery disease regression: hepatic lipase mediated changes in LDL density. Circulation, 99: 19591964, (1999).

[20] Fossati P, Prencipe L, Serum triglycerides determined colorimetrically with an enzyme that produces hydrogen peroxide, Clin Chem.28(10):2077-80, (1982).

[21] Fasce CF, Enzymatic colorimetric method determination of total cholesterol in human serum. Clin Chem, 28: 901-907, (1982).

[22] Senou M, Costa MJ, Massart C, Timmesch M, Khalifa C, Poncin S, Boucquey M, Ge'rard AC, Audinot JN, Dessy C, Ruf J, Feron O, Devuyst O, Guiot Y, Dumont JE, Van Sande J, ManyMC, Role of caveolin-1 in thyroid phenotype, cell homeostasis, and hormone synthesis: in vivo study of caveolin-1 knockout mice. Am J Physiol Endocrinol Metab, 297: E438-E451, (2009).

[23] Bharati V, Kalavathi DR, Shammuga Priya A, Jannathul Firfous S, Anti obesity Effect of Tridax procumbens in artherogenic diet-induce obese rats, 3: 1565-1569, (2011).

[24] Pareek H, Sharma S, Khajja BS, Jain K, Jain GC, Evaluation hypoglycemic and anti-hyperglycemic potential of Tridax procumbens. BMC Complement. Altern.Med, 9: 48, (2009).

[25] Ikewuchi CJ, Alteration of plasma biochemical haematological and ocular oxidative indices of alloxan induced diabetic rats by aqueous extract of Tridax procumbens linn (asteraceae), EXCLI Journal (11) 291308, (2012).

[26] Keerthi S, Padmaja K, Jagadeesh P, Adithya DVSN, Swathi C, Kumar RA, Ravi Teja M, Swamy D and Indira P. Antihyper lipidemic activity of ethanolic extract of Tridax procumbens. IJPCBS 4(4): 874-877, (2014).

[27] Belfort R, Mandarino L, Kashyap S, Wirfel K, Pratipanawatr T, Berria R, DeFronzo RA., and Cusi K: Dose-response effect of elevated plasma free fatty acid on insulin signalling. Diabetes, 54: 1640-1648, (2005).

[28] Gordon DJ, Probstfield JL, Garrisson RJ, High-density lipoprotein cholesterol and cardiovascular disease. Four prospective American studies, Circulation, 79: 8-15 (1989).

[29] Lewington S, Whitlock G, Clarke R, Blood cholesterol and vascular mortality by age, sex, and blood pressure: a meta-analysis of individual data from 61 prospective studies with 55000 vascular deaths. Lancet, 370: 182939, (2007).

[30] De Jong, Plat J, Mensink, RP, Metabolic effects of plant sterols and stanols (review). Journal of Nutritional Biochemistry, 14: 362-9, (2003).

[31] Heistad DD, Oxidative stress and vascular disease, 26 (4): 689-695, (2006).

[32] Madamanchi NR, Vendrov A and Runge MS, Oxidative stress and vascular disease. Arterioscler Thromb Vasc Biol. 25 (1) : 29-38, (2005).

[33] Dougnon TV, Bankolé SH, Klotoé JR, Sènou M, Fah L, Koudokpon $\mathrm{H}$, Akpovi C, Dougnon TJ, Phyllis Addo P, Loko $\mathrm{F}$, Boko $\mathrm{M}$, Treatment of hypercholesterolemia: screening of Solanum macrocarpon Linn (Solanaceae) as a medicinal plant in Benin. AJP, 4(3):160-9, (2014). 
*Corresponding Author:

Koukoui O*

Email:omedine24@gmail.com 